Laboratory tests on insecticidal effectiveness of disodium octaborate tetrahydrate, diatomaceous earth and amorphous silica gel against Sitophilus oryzae (L.) and their effect on wheat bulk density

Laboratorijska testiranja insekticidne učinkovitosti dinatrijevog oktaborat tetrahidrata, dijatomejske zemlje i amorfnoga silika gela na Sitophilus oryzae (L.) te njihov utjecaj na hektolitarsku masu pšenice

Korunić, Z., Rozman, V., Liška, A., Lucié, P.

Poljoprivreda/Agriculture

ISSN: 1848-8080 (Online)

ISSN: 1330-7142 (Print)

http://dx.doi.org/10.18047/poljo.23.1.1

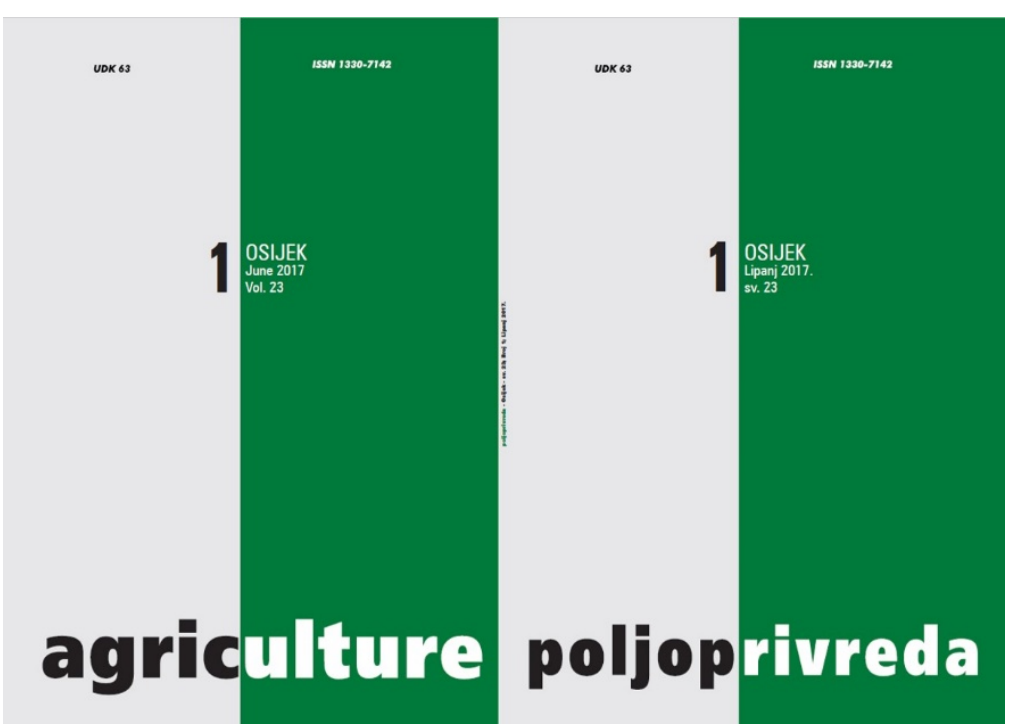

Poljoprivredni fakultet u Osijeku, Poljoprivredni institut Osijek

Faculty of Agriculture in Osijek, Agricultural Institute Osijek 


\title{
LABORATORY TESTS ON INSECTICIDAL EFFECTIVENESS OF DISODIUM OCTABORATE TETRAHYDRATE, DIATOMACEOUS EARTH AND AMORPHOUS SILICA GEL AGAINST Sitophilus oryzae (L.) AND THEIR EFFECT ON WHEAT BULK DENSITY
}

Korunić, Z. ${ }^{(1)}$, Rozman, V.(2), Liška, A. ${ }^{(2)}$, Lucić, $P^{(2)}$

Original scientific paper

Izvorni znanstveni članak

\begin{abstract}
SUMMARY
We examined insecticide effectiveness of three different inert dusts: disodium octaborate tetrahydrate (DOT) and diatomaceous earth (DE) Celatom ${ }^{\circledR}$ Mn 51 applied as powder and suspension, and silica gel Sipernat ${ }^{\circledR} 50 \mathrm{~S}$ applied as powder against Sitophilus oryzae (L.) and their reduction of grain bulk density. Sipernat ${ }^{\circledR} 50 \mathrm{~S}$ was the most effective dust with a very fast initial effectiveness. DE and DOT generated similar effectiveness against $S$. oryzae. DOT generated low initial effectiveness but after prolonged exposure time of 8 and especially after 21 days, the mortality was very high (100\%), similar to the effectiveness of DE. The similar order of dusts was obtained in the reduction of wheat bulk density. Applied at dose of 200 and 500 ppm, the lowest bulk density difference in regard to bulk density of untreated wheat had DOT (-1.1 and $-1.9 \mathrm{~kg} \mathrm{hl}^{-1}$, respectively), followed by Celatom ${ }^{\circledR} \mathrm{Mn} 51$ (-3.5 and $-4.3 \mathrm{~kg} \mathrm{hr}^{-1}$, respectively) and Sipernat ${ }^{\circledR} 50 \mathrm{~S}$ (-5.2 and $-5.5 \mathrm{~kg} \mathrm{hr}^{-1}$, respectively). Due to the effect on wheat bulk density DOT belongs to the group with the least negative effect on bulk density and therefore, it is a promising dust to control stored grain insect pests.
\end{abstract}

Key-words: disodium octaborate tetrahydrate, diatomaceous earth, silica gel, wheat, Sitophilus oryzae (L.), bulk density

\section{INTRODUCTION}

One of the first research publications dealing with inert dust against storage pests is from 1920s (Headlee, 1924). Following this publication, there have been several reviews and research papers on the subject since (Ebeling and Wagner, 1961; Ebeling, 1961, 1971; Fields and Muir, 1996; Golob, 1997; Korunic, 1998, 2013; Quarles, 1992; Quarles and Winn, 1996; Subramanyam and Roesli, 2000; Kalinović et al., 2011; Shah and Khan, 2014; Rozman, 2015; Liška et al., 2015; Malia et al., 2016). Inert dusts are non-toxic dry powders of different origins that are chemically unreactive in nature. Inert dusts can be mixed with different stored agricultural grains to control stored grain pests and different crawling pests in storages and in different industrial objects for food production. Inert dusts do not deteriorate or break down, and therefore, provide long-term control of insect pests and are almost completely harmless to humans and mammals (Maceljski and Korunic (1972), Fields and Muir (1996), Subramanyam and Roesli (2000), Arthur and Puterka (2002), Kljajić et al. (2010) gave detailed guidelines on the key aspects for the use of inert dusts as a possible alternative to synthetic pesticides in stored products, and proposed inert dusts to be included into IPM program.

Unlike conventional contact insecticides, inert dusts function through their physical properties and therefore they generally act more slowly. Insect mortality is induced primarily as a result of water loss

(1) Zlatko Korunić, PhD - Diatom Research and Consulting Inc., 14 Tidefal Dr. Toronto, ON, MW 1J2, Canada, (2) Prof. Dr. Vlatka Rozman, Assoc. Prof. Anita Liška (aliska@pfos.hr); Pavo Lucić, M. Eng. - Josip Juraj Strossmayer University of Osijek, Faculty of Agriculture in Osijek, Vladimira Preloga 1, 31000 Osijek, Croatia 
(desiccation) caused mainly by two ways of mode of actions: destruction of the cuticle with dusts (abrasion) (Alexander et al., 1944a, 1944b) and absorption of waxy layer from insect's cuticle (silica gels and diatomaceous earth containing amorphous silicon dioxide). Other possible causes are blocking the spiracles and causing insects to die from asphyxiation and ingestion of the dust particles causing the gut destruction (Ebeling, 1971; Maceljski and Korunic, 1972; Le Patourel, 1986).

There are advantages and limitations to applying inert dusts. Among the main advantages of using inert dusts, and particularly DEs is their low mammalian toxicity and stability on grain (Korunic, 1998, 2013; Subramanyam and Roesli, 2000). Among the main limitations of using inert dusts including DEs are certain regulatory issues. These issues were reviewed by Korunic $(1998,2013)$, Korunic et al. (1998) and Desmarchelier and Allen (2000).

Silica gel (Sipernat ${ }^{\circledR} 50 \mathrm{~S}$ ) is precipitated hydrophilic silica with high absorption capacity and a large specific surface area of $475 \mathrm{~m}^{2} / \mathrm{g}$. It contains $97-98.5 \%$ of $\mathrm{SiO}_{2}, 1.4 \%$ of $\mathrm{Na}_{2} \mathrm{O}_{3}, \mathrm{Fe}_{2} \mathrm{O}_{3}$ and $\mathrm{SO}_{3}$. It has mean particle size of 7.5 microns, and $\mathrm{pH}$ value (in $5 \%$ suspension) is 6.0. Silica gels are very effective insecticides and acaricides, used in controlling insects, mites and ticks in a variety of indoor and outdoor sites (St. Aubin, 1991). Silica gel is used to control target pests in stored grain crops, food handling areas, hospitals, sewage systems, and on animals/pets and their living quarters (Quarles, 1992).

During the last 20 years, DE has been the subject of several review papers as well (Quarles, 1992; Golob, 1997; Korunic, 1998; Subramanyam and Roesli, 2000; Quarles and Winn, 1996; Nikpay, 2006; Korunic, 2013; Shah and Khan, 2014), with numerous references cited with each review. However, DE is not yet in wider use for direct mixing with grains because of the great obstacles and disadvantages in use (Fields, 1998; Korunić et al. 2016).

Disodium octaborate tetrahydrate (DOT), the inert dust used in the experiment, differs a little bit in the mode of action against insects. Its activity is primarily based on the toxicity and internal desiccation (damaged gut and mouth organ) and less on desiccation through epicuticle (Thurston County Health Department, 2009). These inert dusts are based on boron containing compounds, such as borax (sodium tetraborate decahydrate) and boric acid, and have been used since the early 1900s against ants (Rust, 1986).

The safety of use, stability and the effectiveness of DOT against beetles was the main reason we wanted to assess its effectiveness against stored grain beetles. The choice of safe powdered insecticides used in stored grain protection is very limited; actually, there is only one natural and safe dust in grain protection: diatomaceous earth (DE). The present study was conducted to determine the effectiveness of three chemically and physically different inert dusts to control rice weevil
Sitophilus oryzae (L.) and their effect on grain bulk density (test weight) reduction. It was expected that the most effective inert dust would have higher influence on bulk density reduction of wheat grain than less effective dusts.

\section{MATERIAL AND METHODS}

\section{Inert dusts}

Celatom ${ }^{\circledR}$ MN 51 is a natural diatomaceous earth from the USA (EP Minerals), containing 73.6\% amorphous silica (opal $\mathrm{A}$ ), $7.8 \% \mathrm{Al}_{2} \mathrm{O}_{3}, 5.6 \% \mathrm{CaO}$ and the rest are other oxides. It is beige in colour, with $\mathrm{pH}$ of 7.5 (10\% slurry) and medium particle sizes of 15.0 microns.

Disodium octaborate tetrahydrate (DOT) is odourless white powder of disodium octaborate tetrahydrate, with $\mathrm{pH}$ of 7.6 (in $10 \%$ solution) and extremely low toxicity to warm-blooded organisms. Among many different uses, it is used as an insecticide and fungicide (PPDB: Pesticide Properties DataBase, 2016).

Sipernat ${ }^{\circledR} 50 \mathrm{~S}$ from the USA is precipitated hydrophilic silica with high absorption capacity and a large specific surface area of $475 \mathrm{mg}^{-2}$. It contains $97-98.5 \%$ of amorphous $\mathrm{SiO}_{2}, 1.4 \%$ of $\mathrm{Na}_{2} \mathrm{O}_{3}, \mathrm{Fe}_{2} \mathrm{O}_{3}$ and $\mathrm{SO}_{3}$. It has mean particle size of 7.5 microns, while $\mathrm{pH}$ value is 6.0 (in $5 \%$ suspension).

\section{Test insect}

A laboratory strain of rice weevil Sitophilus oryzae (L.) susceptible to insecticides was used in the experiments. Insects were reared on clean, soft, whole wheat kernels of different variety with approximately $13 \%$ moisture content (m.c.) under controlled conditions $\left(28 \pm 2^{\circ} \mathrm{C}, 65 \pm 5 \%\right.$ r.h., in dark). Fifty unsexed adults (7-21 days old) were used for each treatment.

\section{Bioassays}

DE and DOT samples were sieved through the wire screen with openings of 25 microns. Glass jars were filled with 100 grams of wheat grains of clean Ontario soft wheat of different variety containing approximately $13.6 \%$ m.c. All three dusts were applied as powder and also DE and DOT were applied as suspension (the same dosages of DE and DOT were mixed with water). Each tested dust was applied at 200, 300, 400 and 500 ppm. Following application of the dust and suspensions on the surface of grains, the jars were tightly closed with lid, shaken manually for 1 minute and left closed for 1 hour before the introduction of 50 adults of $S$. oryzae, per each replication. All treatments were set in three replications. The jars with treated grains and test insects were held in a climate chamber at $26 \pm 1^{\circ} \mathrm{C}$ and relative humidity (r.h.) of $55 \pm 5 \%$ during the whole testing period. The assessment of the results was performed after 6, 8 and 21 days and the progeny (F1) production of $S$. oryzae assessment 60 days after the introduction of insects into the replications. 


\section{Bulk density (test weight) reduction measurement}

Five hundred grams of cleaned soft white wheat (with $13.6 \%$ m.c.) were manually mixed with 500 and $200 \mathrm{ppm}$ separately $\left(0.5\right.$ and $\left.0.2 \mathrm{~g} \mathrm{~kg}^{-1}\right)$ of inert dusts in a tightly closed glass jar by shaking for one minute (at room temperature). Test weight was measured using the Canadian Grain Commission procedure (Official Grain Grading Guide, 2016). Measures for both, untreated and treated grain were expressed as kg per hectolitre $\left(\mathrm{kg} \mathrm{hl}^{-1}\right)$. The difference in values between untreated and treated grains showed the reduction of test weight.

\section{Data analysis}

Experimental data were processed by statistical analysis system SAS/STAT Software 9.3. (2013- 2014). One-way analysis of variance of the tested variables was subjected to SAS Analyst module and a procedure ANOVA was used. Tukey's Studentized Range (HSD) test was used to detect differences between means at the 0.05 significance level. Schneider-Orelli formula (Püntener, 1981) was used to calculate corrected efficacy for data on the $7^{\text {th }}$ and $15^{\text {th }}$ day of exposure.

\section{RESULTS AND DISCUSSION}

\section{Insecticidal effectiveness of inert dusts against $S$. oryzae}

In the treatment with DOT powder, the mortality of $S$. oryzae at the 6 days exposure interval was very low even at the highest dose of $500 \mathrm{ppm}$ (36.6\% only) (Table 1). This result indicates a slow initial effectiveness of formulation DOT powder. After 8 days, mortality increased threefold at $300 \mathrm{ppm}$, without significant statistical differences of mortality among higher doses. Furthermore, after 21 days of the exposure, DOT powder reached maximum mortality $(100 \%)$ at $300 \mathrm{ppm}$. DOT powder greatly reduced the progeny of $S$. oryzae even at $200 \mathrm{ppm}(86.1 \%)$ and at higher concentrations from 99.6 to $100 \%$ (Table 2).
Applied as a suspension, DOT showed lower activity overall. The mortality of $S$. oryzae after 6 and 8 days was significantly higher than the control treatment only at the $500 \mathrm{ppm}$ and $400 \mathrm{ppm}$, respectively, still with mortality below $50 \%$. However, after prolonged exposure time of insects on treated grain, the mortality reached its maximum $(100 \%)$ at $300 \mathrm{ppm}$ (Table 1). DOT suspension greatly reduced the progeny of $S$. oryzae even at $200 \mathrm{ppm}(85.4 \%)$ and at higher concentrations from $99.1 \%$ to $99.8 \%$ (Table 2 ).

The initial effectiveness of DE Celatom ${ }^{\circledR} \mathrm{MN} 51$ applied as powder was higher in comparison with this effectiveness of DOT powder. At the lowest dose, the mortality of $S$. oryzae was $52.7 \%, 85.0 \%$ and $77.3 \%$ after 6, 8 and 21 days, respectively (Table 1). At higher doses, statistically significant higher mortality was noticed, reaching the maximum at 500 and $400 \mathrm{ppm}$ after 6 and 21 days of exposure, respectively. The progeny of $S$. oryzae was not completely inhibited at even the highest concentration of $500 \mathrm{ppm}(94.6 \%$ of inhibition) (Table 2).

The effectiveness of DE Celatom ${ }^{\circledR}$ MN 51 applied as a suspension against $S$. oryzae was similar to the results obtained with powder formulation. The only difference was the lower initial effectiveness at the exposure time of 6 days and at $200 \mathrm{ppm}$ concentration after 8 days. Still, the initial effectiveness of DE Celatom ${ }^{\circledR}$ MN 51 suspension was higher in comparison with the effectiveness of DOT powder and DOT suspension (Table 1). Considering the low initial effectiveness against parents, the progeny of $S$. oryzae was not completely inhibited even at the highest concentration of $500 \mathrm{ppm}$ (95.39\%) (Table 2).

In the treatment with Sipernat ${ }^{\circledR} 50$ S powder, the mortality of $S$. oryzae even at $200 \mathrm{ppm}$ after exposure of 8 days was $100 \%$ (Table 1), and also the inhibition of the progeny of $S$. oryzae at all concentrations was $100 \%$ (Table 2).

Table 1. Mortality of $S$. oryzae adults (\%) after 6, 8 and 21 days of exposure to treated wheat grains with inert dusts applied as powder and suspension

Tablica 1. Mortalitet odraslih S. oryzae (\%) u tretiranoj pšenici s inertnim prašivima aplicirani kao prah i suspenzija pri ekspoziciji 6., 8. i 21. dana

\begin{tabular}{|c|c|c|c|c|}
\hline \multirow[b]{2}{*}{$\begin{array}{l}\text { Treatment } \\
\text { Tretman }\end{array}$} & \multirow{2}{*}{$\begin{array}{l}\text { Dose } \\
\text { (ppm) } \\
\text { Doza } \\
(p p m)\end{array}$} & \multicolumn{3}{|c|}{$\begin{array}{l}\text { Exposition (days)* } \\
\text { Izloženost (dani)* }\end{array}$} \\
\hline & & $\begin{array}{c}6 \text { days } \\
\text { (mean } \pm \text { SD) } \\
6 \text { dana } \\
\text { (prosjek } \pm S D \text { ) }\end{array}$ & $\begin{array}{c}8 \text { days } \\
\text { (mean } \pm \text { SD) } \\
8 \text { dana } \\
\text { (prosjek } \pm S D \text { ) }\end{array}$ & $\begin{array}{c}21 \text { days } \\
\text { (mean } \pm \text { SD) } \\
21 \text { dan } \\
\text { (prosjek } \pm S D \text { ) }\end{array}$ \\
\hline \multirow{6}{*}{$\begin{array}{l}\text { DOT } \\
\text { powder } \\
\text { DOT } \\
\text { prašivo }\end{array}$} & 0 & $0.3 \pm 0.57 \mathrm{c}$ & $3.3 \pm 1.15 b$ & $19.3 \pm 3.05 \mathrm{c}$ \\
\hline & 200 & $3.3 \pm 1.15 \mathrm{c}$ & $16.0 \pm 3.60 \mathrm{~b}$ & $94.0 \pm 3.46 \mathrm{~b}$ \\
\hline & 300 & $18.0 \pm 5.29 b$ & $53.0 \pm 10.81 \mathrm{a}$ & $100.0 \pm 0.00 \mathrm{a}$ \\
\hline & 400 & $20.0 \pm 6.00 \mathrm{~b}$ & $50.6 \pm 16.01 \mathrm{a}$ & $100.0 \pm 0.00 \mathrm{a}$ \\
\hline & 500 & $36.6 \pm 6.42 \mathrm{a}$ & $68.3 \pm 8.08 \mathrm{a}$ & $100.0 \pm 0.00 \mathrm{a}$ \\
\hline & $\begin{array}{l}\mathrm{F} \\
P\end{array}$ & $\begin{array}{l}29.88 \\
<.0001\end{array}$ & $\begin{array}{l}24.76 \\
<.0001\end{array}$ & $\begin{array}{l}886.09 \\
<.0001\end{array}$ \\
\hline
\end{tabular}




\begin{tabular}{|c|c|c|c|c|}
\hline \multirow{7}{*}{$\begin{array}{l}\text { DOT } \\
\text { suspension } \\
\text { DOT } \\
\text { suspenzija }\end{array}$} & 0 & $0.0 \pm 0.00 \mathrm{~b}$ & $2.7 \pm 2.30 \mathrm{c}$ & $17.3 \pm 3.05 \mathrm{c}$ \\
\hline & 200 & $5.3 \pm 2.30 \mathrm{~b}$ & $14.7 \pm 2.08 \mathrm{bc}$ & $85.3 \pm 1.52 b$ \\
\hline & 300 & $5.3 \pm 5.03 b$ & $8.7 \pm 5.03 \mathrm{~cd}$ & $100.0 \pm 0.00 \mathrm{a}$ \\
\hline & 400 & $6.7 \pm 1.15 b$ & $22.0 \pm 6.08 \mathrm{~b}$ & $100.0 \pm 0.00 \mathrm{a}$ \\
\hline & 500 & $22.0 \pm 7.21 \mathrm{a}$ & $39.0 \pm 5.19 \mathrm{a}$ & $100.0 \pm 0.00 \mathrm{a}$ \\
\hline & $\mathrm{F}$ & 12.32 & 29.87 & 1656.69 \\
\hline & $P$ & 0.0007 & $<.0001$ & $<. .0001$ \\
\hline \multirow{7}{*}{$\begin{array}{l}\text { Celatom }{ }^{\circledR} \text { Mn } 51 \\
\text { powder } \\
\text { Celatom }{ }^{\circledR} M n 51 \\
\text { prašivo }\end{array}$} & 0 & $0.3 \pm 0.57 \mathrm{~d}$ & $3.3 \pm 1.15 \mathrm{c}$ & $19.3 \pm 3.05 \mathrm{c}$ \\
\hline & 200 & $52.73 \pm 3.05 \mathrm{c}$ & $85.0 \pm 4.25 b$ & $77.3 \pm 6.65 \mathrm{~b}$ \\
\hline & 300 & $90.0 \pm 6.00 \mathrm{~b}$ & $97.7 \pm 3.21 \mathrm{a}$ & $99.7 \pm 0.57$ a \\
\hline & 400 & $93.3 \pm 3.05 \mathrm{ab}$ & $99.7 \pm 0.57$ a & $100.0 \pm 0.00 \mathrm{a}$ \\
\hline & 500 & $100.0 \pm 0.00 \mathrm{a}$ & $100.0 \pm 0.00 \mathrm{a}$ & $100.0 \pm 0.00 \mathrm{a}$ \\
\hline & $\mathrm{F}$ & 474.61 & 842.01 & 338.31 \\
\hline & $P$ & $<.0001$ & $<.0001$ & $<.0001$ \\
\hline \multirow{7}{*}{$\begin{array}{l}\text { Celatom }{ }^{\circledR} \text { Mn } 51 \\
\text { suspension } \\
\text { Celatom }{ }^{\circledR} M n 51 \\
\text { suspenzija }\end{array}$} & 0 & $0.0 \pm 0.00 \mathrm{~b}$ & $2.7 \pm 2.30 \mathrm{c}$ & $17.3 \pm 3.05 \mathrm{c}$ \\
\hline & 200 & $17.3 \pm 6.42 \mathrm{~b}$ & $48.7 \pm 3.05 b$ & $76.3 \pm 3.21 \mathrm{~b}$ \\
\hline & 300 & $52.0 \pm 9.16 \mathrm{a}$ & $94.7 \pm 2.30 \mathrm{a}$ & $98.0 \pm 2.64 \mathrm{a}$ \\
\hline & 400 & $65.3 \pm 6.11 \mathrm{a}$ & $91.0 \pm 7.00 \mathrm{a}$ & $100.0 \pm 0.00 \mathrm{a}$ \\
\hline & 500 & $66.7 \pm 9.85 \mathrm{a}$ & $97.3 \pm 2.88 \mathrm{a}$ & $100.0 \pm 0.00 \mathrm{a}$ \\
\hline & $\mathrm{F}$ & 56.61 & 326.66 & 710.25 \\
\hline & $P$ & $<.0001$ & $<.0001$ & $<.0001$ \\
\hline \multirow{7}{*}{$\begin{array}{l}\text { Sipernat }^{\circledR} 50 \mathrm{~S} \\
\text { powder } \\
\text { Sipernat }^{\circledR} 50 \mathrm{~S} \\
\text { prašivo }\end{array}$} & 0 & $0.3 \pm 0.57 \mathrm{~b}$ & $3.3 \pm 1.15 \mathrm{~b}$ & $19.3 \pm 3.05 b$ \\
\hline & 200 & $96.0 \pm 4.00 \mathrm{~b}$ & $100.0 \pm 0.00 \mathrm{a}$ & $100.0 \pm 0.00 \mathrm{a}$ \\
\hline & 300 & $100.0 \pm 0.00 \mathrm{a}$ & $100.0 \pm 0.00 \mathrm{a}$ & $100.0 \pm 0.00 \mathrm{a}$ \\
\hline & 400 & $100.0 \pm 0.00 \mathrm{a}$ & $100.0 \pm 0.00 \mathrm{a}$ & $100.0 \pm 0.00 \mathrm{a}$ \\
\hline & 500 & $100.0 \pm 0.00 \mathrm{a}$ & $100.0 \pm 0.00 \mathrm{a}$ & $100.0 \pm 0.00 \mathrm{a}$ \\
\hline & $\mathrm{F}$ & 1790.84 & 21025.00 & 2091.57 \\
\hline & $P$ & $<.0001$ & $<.0001$ & $<.0001$ \\
\hline
\end{tabular}

${ }^{*}$ Means in the same column within each exposition time per each treatment followed by the same letters are not significantly different (Tukey's HSD, $P<0.05$ )

*Prosječne vrijednosti u istome stupcu pri istoj izloženosti za pojedini tretman s istim slovom nisu statistički značajno različite (Tukey's HSD, $P<0,05)$

Table 2. Progeny (F1) production of $S$. oryzae 60 days after parent exposure to wheat treated with inert dusts applied as powder and suspension

Tablica 2. Potomstvo (F1) S. oryzae 60 dana nakon izlaganja roditelja tretiranoj pšenici s inertnim prašivima apliciranim kao prah i suspenzija

\begin{tabular}{|l|c|c|c|}
\hline \multirow{2}{*}{ Treatment } & \multirow{2}{*}{$\begin{array}{c}\text { Dose } \\
\text { Tretman }\end{array}$} & \multicolumn{2}{|c|}{$\begin{array}{c}\text { Progeny (F1) production of S. oryzae } \\
\text { Potomstvo (F1) S. oryzae }\end{array}$} \\
\cline { 3 - 4 } & $\begin{array}{c}\text { Doza } \\
(p p m)\end{array}$ & $\begin{array}{c}\text { Number of adults* (mean } \pm \text { SD) } \\
\text { Broj imaga (prosjek } \pm \text { SD) }\end{array}$ & $\begin{array}{c}\text { Percentage of inhibition (\%) } \\
\text { Postotak inhibicije (\%) }\end{array}$ \\
\hline \multirow{3}{*}{ DOT } & 0 & $277.6 \pm 12.69 \mathrm{a}$ & - \\
powder & 200 & $38.6 \pm 6.65 \mathrm{~b}$ & 86.10 \\
DOT & 300 & $1.0 \pm 1.00 \mathrm{c}$ & 99.64 \\
prašivo & 400 & $0.6 \pm 0.57 \mathrm{c}$ & 99.79 \\
& 500 & $0.0 \pm 0.00 \mathrm{c}$ & 100.00 \\
& $\mathrm{~F}$ & 1049.93 & \\
\hline & $P$ & $<.0001$ & - \\
DOT & 0 & $338.3 \pm 40.85 \mathrm{a}$ & 85.43 \\
suspension & 200 & $49.3 \pm 24.70 \mathrm{~b}$ & 99.12 \\
DOT & 300 & $3.0 \pm 2.00 \mathrm{~b}$ & 99.71 \\
suspenzija & 400 & $1.0 \pm 0.00 \mathrm{~b}$ & 99.83 \\
& 500 & $0.6 \pm 1.15 \mathrm{~b}$ & \\
\hline
\end{tabular}




\begin{tabular}{|c|c|c|c|}
\hline $\begin{array}{l}\text { Celatom }{ }^{\circledR} \text { Mn } 51 \\
\text { powder } \\
\text { Celatom }{ }^{\circledR} \text { Mn } 51 \\
\text { prašivo }\end{array}$ & $\begin{array}{c}0 \\
200 \\
300 \\
400 \\
500 \\
F \\
P\end{array}$ & $\begin{array}{c}277.6 \pm 14.18 \mathrm{a} \\
80.6 \pm 4.72 \mathrm{~b} \\
64.0 \pm 10.44 \mathrm{~b} \\
36.3 \pm 12.09 \mathrm{c} \\
15.0 \pm 4.00 \mathrm{c} \\
336.17 \\
<.0001\end{array}$ & $\begin{array}{c}- \\
70.97 \\
76.95 \\
86.91 \\
94.60\end{array}$ \\
\hline $\begin{array}{l}\text { Celatom }{ }^{\circledR} \text { Mn } 51 \\
\text { suspension } \\
\text { Celatom }^{\circledR} M n 51 \\
\text { suspenzija }\end{array}$ & $\begin{array}{c}0 \\
200 \\
300 \\
400 \\
500 \\
F \\
P\end{array}$ & $\begin{array}{c}338.3 \pm 40.85 \mathrm{a} \\
185.3 \pm 16.80 \mathrm{~b} \\
83.3 \pm 10.96 \mathrm{c} \\
40.6 \pm 12.66 \mathrm{~cd} \\
15.6 \pm 5.03 \mathrm{~d} \\
115.70 \\
<.0001\end{array}$ & $\begin{array}{c}- \\
45.23 \\
75.38 \\
88.00 \\
95.39\end{array}$ \\
\hline $\begin{array}{l}\text { Sipernat }^{\circledR} 50 \mathrm{~S} \\
\text { powder } \\
\text { Sipernat }{ }^{\circledR} 50 \mathrm{~S} \\
\text { prašivo }\end{array}$ & $\begin{array}{c}0 \\
200 \\
300 \\
400 \\
500 \\
F \\
P\end{array}$ & $\begin{array}{c}277.6 \pm 14.18 \mathrm{a} \\
0.0 \pm 0.00 \mathrm{~b} \\
0.0 \pm 0.00 \mathrm{~b} \\
0.0 \pm 0.00 \mathrm{~b} \\
0.0 \pm 0.00 \mathrm{~b} \\
1148.82 \\
<.0001\end{array}$ & $\begin{array}{c}- \\
100.00 \\
100.00 \\
100.00 \\
100.00\end{array}$ \\
\hline
\end{tabular}

aMeans in the same column within each treatment followed by the same letters are not significantly different (Tukey's HSD, $P<0.05)$

${ }^{a}$ Srednje vrijednosti u istome stupcu s istim slovom nisu statistički značajno različite (Tukey's $H S D, P<0,05$ )

Effect of inert dusts on wheat bulk density (test weight)

The results of the effect of inert dusts on bulk density reduction (test weight) indicated quite clearly that the most effective inert dusts silica gel Sipernat ${ }^{\circledR}$ $50 \mathrm{~S}$ reduced test weight from $5.2(200 \mathrm{ppm})$ to $5.5 \mathrm{~kg}$ $\mathrm{hl}^{-1}(500 \mathrm{ppm})$, significantly lower than less effective dusts DE Celatom ${ }^{\circledR}$ MN 51 reducing test weight from $3.5 \mathrm{~kg} \mathrm{hl}^{-1}$ (200 ppm) to $4.3 \mathrm{~kg} \mathrm{hl}^{-1}$ (500 ppm) (Table 3). However, DOT reduced test weight for only 1.1 to $1.9 \mathrm{~kg}$ $\mathrm{hl}^{-1}$ at 200 and $500 \mathrm{ppm}$, respectively (Table 3).

Table 3. Influence of inert dusts applied as powder on bulk density $\left(\mathrm{kg} \mathrm{hl}^{-1}\right)$ of treated wheat

Tablica 3. Utjecaj inertnih prašiva apliciranih kao prašivo na hektolitarsku masu $\left(\mathrm{kg} \mathrm{h}^{-1}\right)$ tretirane pšenice

\begin{tabular}{|c|c|c|c|}
\hline $\begin{array}{l}\text { Treatment } \\
\text { Tretman }\end{array}$ & $\begin{array}{l}\text { Dose } \\
\text { (ppm) } \\
\text { Doza } \\
(p p m)\end{array}$ & 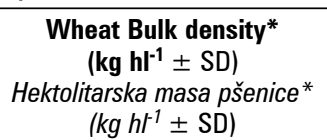 & 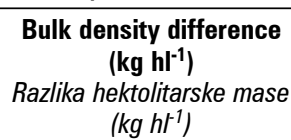 \\
\hline $\begin{array}{l}\text { Untreated } \\
\text { Bez tretmana }\end{array}$ & 0 & $76.6 \pm 0.11 \mathrm{a}$ & - \\
\hline \multirow{2}{*}{ DOT } & 200 & $75.5 \pm 0.37 b$ & -1.1 \\
\hline & 500 & $74.7 \pm 0.15 c$ & -1.9 \\
\hline \multirow{2}{*}{ Celatom ${ }^{\circledR} \mathrm{Mn} 51$} & 200 & $73.1 \pm 0.25 d$ & -3.5 \\
\hline & 500 & $72.3 \pm 0.40 \mathrm{e}$ & -4.3 \\
\hline \multirow{2}{*}{ Sipernat ${ }^{\circledR} 50 \mathrm{~S}$} & 200 & $71.1 \pm 0.15 f$ & -5.2 \\
\hline & 500 & $71.4 \pm 0.36 \mathrm{f}$ & -5.5 \\
\hline $\mathrm{F}$ & & 163.34 & \\
\hline$P$ & & $<.0001$ & \\
\hline
\end{tabular}

*Means in the same column followed by the same letters are not significantly different (Tukey's HSD, $P<0.05$ )

*Srednje vrijednosti u istome stupcu s istim slovom nisu značajno različite (Tukey's HSD, $P<0,05$ )

Sipernat ${ }^{\circledR} 50$ S had the best effectiveness against $S$. oryzae, reaching $100 \%$ mortality at 300 ppm 6 days posttreatment, followed by DE Celatom ${ }^{\circledR}$ MN 51 applied as powder, reaching maximum mortality with 500 ppm at the same exposition time, although the same rank of activity was achieved with lower doses $(93.3 \%$ at $400 \mathrm{ppm})$, and at longer exposure $\left(97.7 \%\right.$ and $99.7 \%$, respectively, at 300 ppm). Applied as a suspension, DE Celatom ${ }^{\circledR}$ MN 51 was slightly less effective, reaching $100 \%$ mortality at $400 \mathrm{ppm}$ after 21 days post-treatment. DOT was equally effective as powder and suspension achieving $100 \%$ mortality at 300 ppm after 21 days. All tested inert dusts had significant impact on progeny 
inhibition even at the lowest dose, while Sipernat ${ }^{\circledR} 50$ S accomplished complete progeny inhibition. In the treatment with DOT applied as a powder and suspension, the percentage of inhibition ranged from $86.1 \%$ to $100.0 \%$, and from $85.43 \%$ to $99.83 \%$, respectively, depending on the dose. In spite of the better initial efficacy of DE Celatom ${ }^{\circledR}$ MN 51 and efficacy of DOT after 6 and 8 days applied as powder and suspension against $S$. oryzae, an overall percentage of inhibition was lower.

Concerning the impact on quality of treated wheat with tested inert dusts, a significant effect on wheat bulk density reduction was recorded.

The active substance of silica gels, synthetic amorphous silicon dioxide, was reviewed for use in insect control (Quarles, 1992) and in Regulation (EU) n⿳528/2012, March 2014, Product Type Insecticides, acaricides and products to control other arthropods (PT18), considering professional uses only. This substance is acceptable and safe for application by Pest Control Operators to control insects (cockroaches). Rat $\mathrm{LD}_{50}$ oral is $>5000 \mathrm{mg} \mathrm{kg}^{-1}$ for various silica gels; rat $\mathrm{LD}_{50}$ dermal is $>2000$ for various silica gels as well (Assessment Report France, 2014). Liška et al. (2017) conducted experiments with silica gels Sipernat ${ }^{\circledR} 50 \mathrm{~S}$, Aerosil $^{\circledR} 200$, several DEs and some other inert dusts in order to determine the effectiveness against $S$. oryzae and found out the highest effectiveness of silica gels in comparison with the effectiveness of other inert dusts in the experiment.

During the last 20 years, DE has been the subject of several review papers as well (Quarles, 1992; Golob, 1997; Korunic, 1998, 2013; Subramanyam and Roesli, 2000; Fields and Korunic, 2000; Quarles and Winn. 1996; Nikpay, 2006; Shah and Khan, 2014; Korunić et al., 2016), with numerous references cited within each. Such comprehensive lists of hundreds of references show the great interest in the research of DE to be used as a safe grain protectant. The most extensive research with $D E$ conducted by numerous researchers has been made in the field of the protection of stored agricultural products (Korunic, 1998, 2013; Kljajic et al., 2010). However, DE is not yet in wider use for direct mixing with grains to be placed on the market because of the great obstacles and disadvantages in use. The main obstacles are the unacceptable effect on grain flowability, the effect on bulk density or test weight shifting grains in lower grain grade, the different tolerance of insect species to DEs, the significant effect of grain moisture and temperature on the activity against insects, and the significant effect of different commodities on the effectiveness of DEs against insects (Korunic, 2016). Because of all these significant and unacceptable disadvantages in direct mixing with grains, it is quite obvious that nowadays the use of $\mathrm{DE}$ as a grain protectant has minimal or hardly any opportunity of being accepted by grain industry. Therefore, it is very important to continue to work on the discovery of another type of safe, effective, inert dust that has minimal adverse effect on bulk density and grain flowability to partly replace $D E$ in direct mixing with grains. However, DEs may have a wider application on farms to protect grains for their own use and for structural treatment in grain and the food industry (Korunic, 2016).

Disodium octaborate tetrahydrate (DOT) is a white, odourless, powdered substance containing the basic elements of boron and oxygen, and presents little or no hazard to humans. It is not flammable, combustible, or explosive and has low acute oral and dermal toxicity. Oral $L_{50}$ is $>2000 \mathrm{mg} \mathrm{kg}^{-1}$ (rat), dermal LD 50 is $>2000 \mathrm{mg} \mathrm{kg}^{-1}$ (rat) (PPDB: Pesticide Properties DataBase, 2016). DOT possess a very good effectiveness against pests and fungus. It is most often used in pest control products that are designed to target wood destroying insects such as termites, carpenter ants, and powder post beetles. Several formulations of DOT may be found on the market: Tim-bor ${ }^{\circledR}$, Polybor ${ }^{\circledR}$, BoraCare ${ }^{\circledR}$, Borathor ${ }^{\circledR}$, Termite Prufe ${ }^{\circledR}$ and Board Defense ${ }^{\circledR}$ usually containing about $98 \%$ of DOT. Borate compounds like DOT utilize a stop-feed mode of action. Stop-feed means that the active ingredient DOT disrupts the enzyme and digestive systems of the insect, preventing future digestion and causing death by starvation. These products are very stable and do not degrade or break down (Thurston County Health Department, 2009).

\section{CONCLUSION}

As a result of all these negative effects on grain quality and handling, the use of inert dusts, including DEs, is still in limited use in larger storage facilities. Based on the analysis of the significant effects on bulk density reduction and grain handling, we believe that inert dusts DE Celatom ${ }^{\circledR}$ MN 51 and Sipernat ${ }^{\circledR} 50$ S can hardly be accepted by grain industry for mixing with grains. However, because of its acceptable effectiveness and minimal effect on bulk density reduction (test weight), inert dust DOT applied at 200 to $500 \mathrm{ppm}$ is, among the three types of inert dusts, the most promising dust for grain protection when directly mixed with grains. In authors' opinion, that dust when mixed with grains may have wider use in stored grain protection.

\section{REFERENCES}

1. Alexander, P., Kitchener, J.A., Briscoe, H.V.A. (1944a): Inert dust insecticides: Part I. Mechanism of action. Annals of Applied Biology, 31(2):143-149.

doi: http://dx.doi.org/10.1111/j.1744-7348.1944. tb06225.x

2. Alexander, P., Kitchener, J.A., Briscoe, H.V.A. (1944b): Inert dust insecticides: Part II. The nature of effective dusts. Annals of Applied Biology, 31(2):150-156.

doi: http://dx.doi.org/10.1111/j.1744-7348.1944. tb06226.X

3. Arthur, F.H., Puterka, G.J. (2002): Evaluation of kaolinite-based particle films to control Tribolium species 
(Coleoptera: Tenebrionidae). Journal of Stored Products Research, 38:341-348.

doi: http://dx.doi.org/10.1016/S0022-474X(01)00036-4

4. Assessment Report France, (2014): Synthetic amorphous silicon dioxide March 2014 Evaluation of active substances. Regulation (EU) n528/2012, March 2014:135.

5. Desmarchelier, K.M., Allen, S.E. (2000): Diatomaceous earth: health, safety, environment, residues and regulatory issues. In: Proceedings $7^{\text {th }}$ International Working Conference on Stored-product Protection, Beijing, PR China, Vol.1: 758-764.

6. Ebeling, W. (1971): Sorptive Dusts for Pest Control. Annual Review of Entomology, 16(1):123-158.

doi: http://dx.doi.org/10.1146/annurev. en.16.010171.001011

7. Ebeling, W. (1961): Physicochemical mechanisms for the removal of insect wax by means of finely divided powders. Hilgardia, 30:531-564.

doi: http://dx.doi.org/10.3733/hilg.v30n18p531

8. Ebeling, W., Wagner, R. (1961): Relation of lipid adsorptivity of powders to their suitability as insecticide diluents. Hilgardia, 30(18):565-586.

doi: http://dx.doi.org/10.3733/hilg.v30n18p565

9. Fields, P.G., Muir, W.E. (1996): Physical Control. In Subramanyam \& D.W. Hagstrum (Eds.), Integrated Management of Insect in Stored Products. NewYork: Marcel-Dekker Inc.:195-221.

10. Fields, P.G. (1998): Diatomaceous earth: Advantages and limitations. In: Jin. Z., Liang, Q., Liang, Y., Tan, X., Guan, L. (Eds), Proceedings of the $7^{\text {th }}$ International Conference on Stored-Product Protection, 14-19 October 1998, Beijing, P.R. China, Sichuan Publishing House of Science and Technology, Chengdu, Sichuan Province, P.R. China, Vol. 1:781-784.

11. Golob, P. (1997): Current status and future perspectives for inert dusts for control of stored product insects. Journal of Stored Products Research, 33(1):69-79. doi: http://dx.doi.org/10.1016/S0022-474X (96)00031-8

12. Headlee, T.J. (1924): Certain dusts as agents for protection of stored seeds from insect infestation. Journal of Economic Entomology, 17:298-307. doi: http://doi.org/10.1093/jee/17.2.298

13. Kalinović, I., Korunić, Z., Rozman, V., Liška, A. (2011): Djelotvornost dijatomejske zemlje i mješavina dijatomejske zemlje i piretrina (Effectivness of pure diatomaceus earth and different mixtures of diatomaceus earth with pyrethrins). Poljoprivreda/Agriculture/, 17(2):13-17.

14. Kljajić P., Andrić, G., Adamović, M., Bodroža-Solarov, M., Marković, M., Perić I. (2010): Laboratory assessment of insecticidal effectiveness of natural zeolite and diatomaceous earth formulations against three stored-product beetle pests. Journal of Stored Product Research, 46:1-6. doi: http://dx.doi.org/10.1016/j.jspr.2009.07.001

15. Korunić, Z., Rozman, V., Liška, A., Lucić, P. (2016): A review of natural insecticides based on diatomaceous earths. Poljoprivreda/Agriculture, 22(1):10-18. doi: http://dx.doi.org/10.18047/poljo.22.1.2
16. Korunic, Z. (2016): Overview of undesirable effects of using diatomaceous earths for direct mixing with grains. Pestic. Phytomed. (Belgrade), 31(1-2):9-18. doi: http://dx.doi.org/10.2298/PIF1602009K

17. Korunic, Z. (2013): Diatomaceous earths - Natural Insecticides. Pesticides \& Phytomedicine (Belgrade) 28(2):77-95.

doi: http://dx.doi.org/10.2298/PIF1302077K

18. Korunic, Z. (1998): Review Diatomaceous earths, a group of natural insecticides. Journal of Stored Products Research, 34(2-3):87-97. doi: http://dx.doi.org/10.1016/S0022-474X(97)00039-8

19. Korunic, Z., Cenkovski, S., Fields, P.G. (1998): Grain bulk density as affected by diatomaceous earths and application method. Postharvest Biology and Technology, 13:8189.

doi: http://dx.doi.org/10.1016/S0925-5214(97)00076-8

20. Le Patourel, G.N.J. (1986): The effect of grain moisture content on the toxicity of a sorptive silica dust to four species of grain beetle. Journal of Stored Products Research, 22:63-69.

doi: http://dx.doi.org/10.1016/0022-474X(86)90020-2

21. Liška, A., Korunić, Z., Rozman, V., Halamić, J., Galović, I., Lucić, P., Baličević, R. (2017): The effect of inert dusts on wheat bulk density and effectiveness against rice weevil Sitophilus oryzae (L.). Proceedings of the $29^{\text {th }}$ Seminar DDD and ZUPP 2017 Disinfection, Disinfestation, Deratization and Protection of Stored Agricultural Products, Zagreb, Croatia: 277-289.

22. Liška, A., Rozman, V., Korunić, Z., Halamić, J., Galović, I., Lucić, P., Baličević, R. (2015): The potential of Croatian diatomaceous earths as grain protectant against three stored-product insects. Integrated Protection of Stored Products IOBC-WPRS Bulletin Vol. 111, 2015:107-113.

23. Maceljski, M., Korunic, Z. (1972): The Effectiveness against Stored-Product Insects of Inert Dusts, Insect Pathogens, Temperature and Humidity. Project No.E30MQ-1. Grant USDA/YU No. FG -YU - 130. Final Report of Institute for Plant Protection. Zagreb, Croatia.

24. Malia, H.A.E., Rosi-Denadai, C.A., Guedes, N.M.P., Martins, G.F., Guedes, R.N.C. (2016): Diatomaceous earth impairment of water balance in the maize weevil, Sitophilus zeamais. Journal of Pest Science, 89 (4):945954.

doi: http://dx.doi.org/10.1007/s10340-016-0732-0

25. Nikpay, A. (2006): Diatomaceous earths as alternatives to chemical insecticides in stored grain. Insect Science, 13(6):421-429.

doi: http://dx.doi.org/10.1111/j.1744-7917.2006.00111.x

26. Official Grain Grading Guide, (2016): Determining test weight. https://www.grainscanada.gc.ca/oggg-gocg/01test-weight-2016-eng.pdf

27. PPDB: Pesticide Properties DataBase, (2016): Disodium octaborate tetrahydrate. http://sitem.herts.ac.uk/aeru/ ppdb/en/Reports/2134.htm

28. Püntener, W. (1981): Manual for field trials in plant protection second edition. Agricultural Division, Ciba-Geigy Limited, pp: 205. 
29. Quarles, W. (1992): Silica gel for pest control. IPM Practitioner, 14(7):1-11.

30. Quarles, W., Winn, P. (1996): Diatomaceous Earth and Stored Product Pests. IPM Practitioner, 18(5-6): 1-10.

31. Rozman, V. (2015): Control of stored products pests by natural products. Integrated Protection of Stored Products IOBC-WPRS Bulletin, 111: 295-299.

32. Rust, M.K. (1986): Managing household pests. In G.W. Bennett and J.M. Owens [eds.], Advances in urban pest management. Van Nostrand Reinhold, New York: 335368.

33. SAS 9.3 Copyright (c) 2013-2014 by SAS Institut Inc., Cary, NC, USA (Licensed to Poljoprivredni fakultet Osijek T/R Site 70119033

34. Shah, M.A., Khan, A.A. (2014): Use of diatomaceous earth for the management of stored-product pests.
International Journal of Pest Management, 60(2):100113.

doi: http://dx.doi.org/10.1080/09670874.2014.918674

35. St. Aubin, Forrest (1991): Everything old is new again. Pest Control. Technol. June: 50:52. 102

36. Subramanyam, B.H., Roesli, R. (2000): Inert dusts. In (Bh. Subramanyam \& D.W. Hagstrum (Eds.), Alternatives to Pesticides in Stored-Product IPM. Dordreecht: Kluwer Academic Publishers: 321-380.

doi: http://dx.doi.org/10.1007/978-1-4615-4353-4_12

37. Thurston County Health Department, (2009): Disodium octaborate tetrahydrate.

http://www.co.thurston.wa.us/health/ehipm/pdf insect/insecticide\%20actives/Disodium $\% 20$ octaborate $\% 20$ tetrahydrate.pdf

\section{LABORATORIJSKA TESTIRANJA INSEKTICIDNE UČINKOVITOSTI DINATRIJEVOG OKTABORAT TETRAHIDRATA, DIJATOMEJSKE ZEMLJE I AMORFNOGA SILIKA GELA NA Sitophilus oryzae (L.) TE NJIHOV UTJECAJ NA HEKTOLITARSKU MASU PŠENICE}

\section{SAŽETAK}

Istraživali smo insekticidnu učinkovitost tri različita inertna prašiva: dinatrijev oktaborat tetrahidrat (DOT) $i$ dijatomejsku zemlju (DZ) Celatom ${ }^{\circledR}$ Mn 51 primijenjenih kao prašivo i suspenzija i silika gel Sipernat ${ }^{\circledR} 50$ S u obliku prašiva na Sitophilus oryzae (L.) te njihov utjecaj na smanjenje hektolitarske mase. Sipernat ${ }^{\circledR} 50$ S bio najučinkovitije je prašivo s vrlo brzim inicijalnim djelovanjem. DZ i DOT imaju sličnu učinkovitost na $S$. oryzae. DOT je imao nisko inicijalno djelovanje, no nakon produženog izlaganja od 8., a osobito 21. dana, mortalitet je vrlo visok (100\%), slično djelovanju DZ-a. Sličan slijed prašiva zabilježen je $i$ kod utjecaja na smanjenje hektolitarske mase. Pri dozama od 200 i 500 ppm, najmanju razliku u hektolitarskoj masi u odnosu na hektolitarsku masu netretirane pšenice imao je DOT $\left(-1,1\right.$ i -1,9 $\mathrm{kg} \mathrm{hl}^{-1}$, kako slijedi), potom Celatom ${ }^{\circledR}$ MN

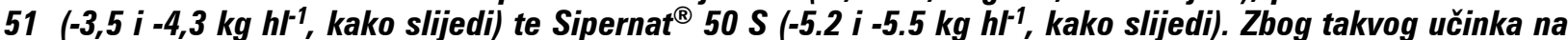
hektolitarsku masu pšenice, DOT pripada u skupinu s najslabijim negativnim učinkom na hektolitarsku masu $i$ stoga je obećavajuće prašivo u suzbijanju štetnika na uskladištenoj pšenici.-

Ključne riječi: dinatrijev oktaborat tetrahidrat, dijatomejska zemlja, silika gel, pšenica, Sitophilus oryzae (L.), hektolitarska masa

(Received on 28 February 2017; accepted on 24 April 2017 - Primljeno 28. veljače 2017.; prihvaćeno 24. travnja 2017.) 